\title{
Qibla Direction Correction Test using a Digital Compass and Arduino Microcontroller
}

\author{
Raden Apip Miptahudin, Muhammad Aris Risnandar, W. S. Mada Sanjaya, \\ Mustafa Mamat, Aceng Sambas, Mohamad Afendee Mohamed
}

\begin{abstract}
Qibla is an Arabic word that refers to the direction in which a Muslim establishes prayer. In this study, we made a Qibla-based digital compass and Arduino microprocessor construction. The spherical trigonometry method is used to find out the direction of the Qibla by getting cross lines and longitude. While the direction of the qibla is obtained with the help of a digital compass. The testing of this tool was carried out at the mosque in Indonesia. The results showed that the direction of the Qibla for the Nur Asmaul Husna Mosque (Banten Province) is located at $295.2077026^{\circ}$ with a correction of $-0.06^{\circ}$. Gedhe Kauman Mosque is (Yogyakarta City) located at $294.7148437^{\circ}$ with a correction of $-0.35^{\circ}$ and the Jami Nurul Muminin mosque is located at $294.0274353^{\circ}$ with a correction of $-9.74^{\circ}$. A small correction value indicates the accuracy of the Qibla direction.
\end{abstract}

Index Terms: Chaos, hidden attractor, synchronization, numerical simulation, circuit design.

\section{INTRODUCTION}

In modern times, combining various features or capabilities in one device has become a trend for various electronic devices, for example mobile phones. In this study, using two devices namely the Global Positioning System (GPS) and digital compass. The GPS itself is a satellite navigation system that works well. This system uses 24 satellites to transmit microwaves to Earth that are received by a tool. Then this digital compass is assumed to be outdoors and free from the influence of magnetic fields. Because of the use of GPS less optimal when in the room and also the performance of a digital compass which will be disturbed when in a magnetic field area. By applying mathematical calculations, this tool will be able to minimize errors about Qibla direction.

Qibla is an important part of a Muslim to worship. Some methods related to Qibla direction are theodolite assistive

Revised Manuscript Received on April 25, 2019.

R. Apip Miptahudin, Department of Electrical Engineering, Universitas Muhammadiyah Tasikmalaya, Indonesia.

M. Aris Risnandar, Department of Electrical Engineering, Universitas Muhammadiyah Tasikmalaya, Indonesia .

W. S. Mada Sanjaya, Departement of Physics, Universitas Islam Negri Sunan Gunung Djati, Bandung, Indonesia.

Mustafa Mamat, Faculty of Informating and Computing, Universiti Sultan Zainal Abidin Malaysia.

Aceng Sambas, Department of Mechanical Engineering, Universitas Muhammadiyah Tasikmalaya, Indonesia.

Mohamad Afendee Mohamed, Faculty of Informating and Computing, Universiti Sultan Zainal Abidin Malaysia. methods [1], azimuth months [2], right triangles [3], Global Positioning System (GPS) [4], spherical trigonometry and gnomon shadows by the sun [5 ], Robot prototype [6], analog watch circle [7] and wind gusts [8].

Some literature related to Qibla measuring devices using technology is presented in this section. In 2006, Isa et al. Presented a preliminary study on how to develop GUI-based software, which can determine prayer times in real-time flight and Qibla direction [9]. In 2009, Ibrahim et al created a new electronic device called Mobile Qibla and Prayer Time Finder to find the Qibla direction and to determine each prayer time based on the user's current location using a PDA. This device uses a PIC microcontroller that is equipped with a digital compass where it will communicate with PDAs using Bluetooth technology and automatically displays the Qibla direction and prayer times anywhere in the world [10]. In 2016, Jassim et al. Made a new study to determine the Qibla direction that applies globally to different users precisely in relation to the actual north direction without the need to use expensive Gyrotheodolites or inaccurate compasses. The exact equation has been included in a stand-alone program algorithm to direct the Qibla direction using GNSS by providing a report on error analysis in the direction obtained [11].

In this work, we made a Qibla-based digital compass and Arduino microprocessor construction. The spherical trigonometry method is used to find out the direction of the Qibla by getting cross lines and longitude. While the direction of the qibla is obtained with the help of a digital compass.

\section{LITERATUR REVIEW}

Flat-angle measurement is applied to the spherical surface of the earth we live in. Developed for the first time by Albattani, Alkhawarizmi, and Albiruni which developed into a science of Geodesy.

The spherical triangle becomes the science for calculating the Qibla direction. Direction is the shortest distance in the form of a straight line to a place, the qibla shows the shortest direction to the Kaaba. Because of the round shape of the earth, this line forms a large arc along the surface of the earth. Based on Google Earth, the latitude of Kaaba is $\varphi=21^{\circ} .25^{\prime} 21.17^{\prime \prime} L U$ The longitude of the Ka'bah is $\lambda=39^{\circ} 49^{\prime} 34.56^{\prime \prime} B T$.

Based on the spherical triangular trigonometry, the equation for determining the Qibla direction in location is shown in equation (1). 


$$
\tan (Q)=\frac{\sin \left(\lambda_{L}-\lambda_{M}\right)}{\cos \varphi_{L} \tan \varphi_{M}-\sin \varphi_{L} \cos \left(\lambda_{L}-\lambda_{M}\right)}
$$

The Equation (1), describe:

$\varphi_{M}=$ Makkah (Qibla) Latitude

$\lambda_{M}=$ Makkah (Qibla) Longitude,

$\varphi_{L} \quad=$ The Latitude of some location

$\lambda_{L} \quad=$ The Longitude of a location to determine Qibla direction.

\section{RESEARCH METHODS}

In this section, the design of a tool system for Qibla direction is explained. General system based on GPS modules, compass modules and Arduino microcontrollers. The system writing algorithm uses Arduino IDLE. The steps in this case are general research shown in Fig. 1.

Generally, the process of this work is to make it easy for technology users who have GPS devices especially for Muslims to know the Qibla direction when they will worship in a new location. So that Muslims can find out the direction of the Qibla from their current position. The coordinates obtained by the GPS receiver, when the map is displayed, do shift markers after comparing the position in the real world so that it has a high degree of accuracy.

In Fig. 1, Arduino, GPS module and Compass will be activated automatically. The GPS device will get the Longitude and Latitude of a particular Location (which will be known the Qibla direction). Whereas the Digital Compass gets Location and North angles. Compass data is calculated to get the location angle towards the Qibla.

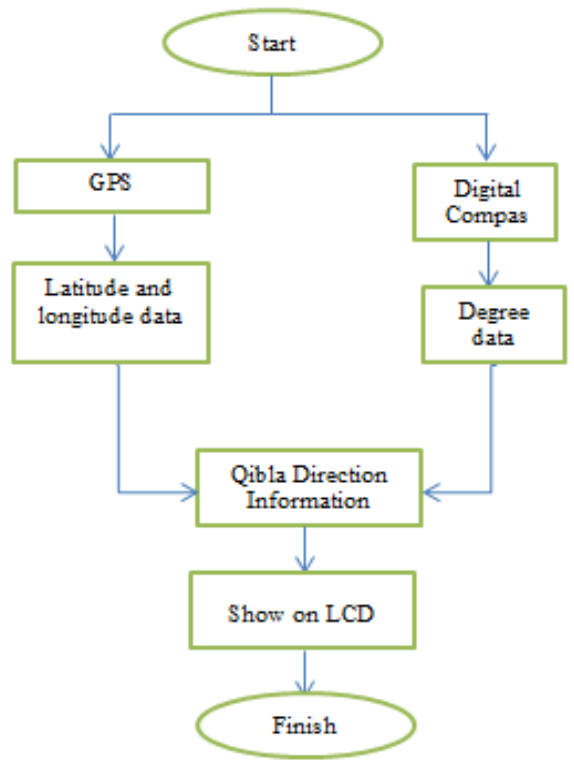

Fig. 1. General scheme of the research system.

\section{RESULTS AND DISCUSSION}

To design a device that can detect Qibla direction, a GPS and digital compass are needed. The first step in designing a tool for Qibla direction is to need a digital compass value calibration (Module HMC5883L) that is compared with a manual compass as literature. Table 1 is the calibration value of the wind direction (after the linear regression results) of the digital compass.

GPS and Compass data are processed using spherical triangular trigonometry formulations (see Equation (1)) which will produce Qibla direction and mosque correction data. The results showed that the direction of the Qibla for the Nur Asmaul Husna Mosque (Banten Province) is located at $295.2077026^{\circ}$ with a correction of $-0.06^{\circ}$. Gedhe Kauman Mosque is (Yogyakarta City) located at $294.7148437^{\circ}$ with a correction of $-0.35^{\circ}$ and the Jami Nurul Muminin mosque (East Java) is located at $294.0274353^{\circ}$ with a correction of $-9.74^{\circ}$. A small correction value indicates the accuracy of the Qibla direction (See Fig. 2).

Table 1 Digital compass calibration data

\begin{tabular}{|c|c|c|c|c|}
\hline No & $\begin{array}{l}\text { Direction of } \\
\text { Compass }\end{array}$ & $\begin{array}{l}\text { Digital } \\
\text { Compass }\end{array}$ & $\begin{array}{l}\text { Manual } \\
\text { Compass }\end{array}$ & Difference \\
\hline 1 & North & $316^{\circ}$ & $360^{\circ}$ & $44^{\circ}$ \\
\hline 2 & East & $135^{\circ}$ & $90^{\circ}$ & $45^{\circ}$ \\
\hline 3 & South & $202^{\circ}$ & $180^{\circ}$ & $22^{\circ}$ \\
\hline 4 & West & $250^{\circ}$ & $270^{\circ}$ & $20^{\circ}$ \\
\hline
\end{tabular}

Because the HMC5883L compass module is not equipped with magnetic declination and the GY-NEO6MV2 GPS module cannot access magnetic declination, the digital compass module needs to be recalibrated by adding magnetic declination every place

From the results of data retrieval shown in Fig. 2 a correction is needed before the prayer in several mosques. One easy solution to correct the direction of the mosque prayer / prayer can use a way to correct the direction of the carpet.

\section{CONCLUSION}

In this study, a tool has been developed that can determine the direction of Qibla based digital compass. This tool is built with an Arduino microcontroller, a GPS module, and the Kompas module can work well and is designed so that it can be carried anywhere (portable). The spherical triangular trigonometry method is used to determine the direction of the Qibla from the Latitude and Longitude data of a location. The results showed that the direction of the Qibla for the Nur Asmaul Husna Mosque (Banten Province) is located at $295.2077026^{\circ}$ with a correction of $-0.06^{\circ}$. Gedhe Kauman Mosque is (Yogyakarta City) located at $294.7148437^{\circ}$ with a correction of $-0.35^{\circ}$ and the Jami Nurul Muminin mosque (East Java) is located at $294.0274353^{\circ}$ with a correction of $-9.74^{\circ}$. A small correction value indicates the accuracy of the Qibla direction. 


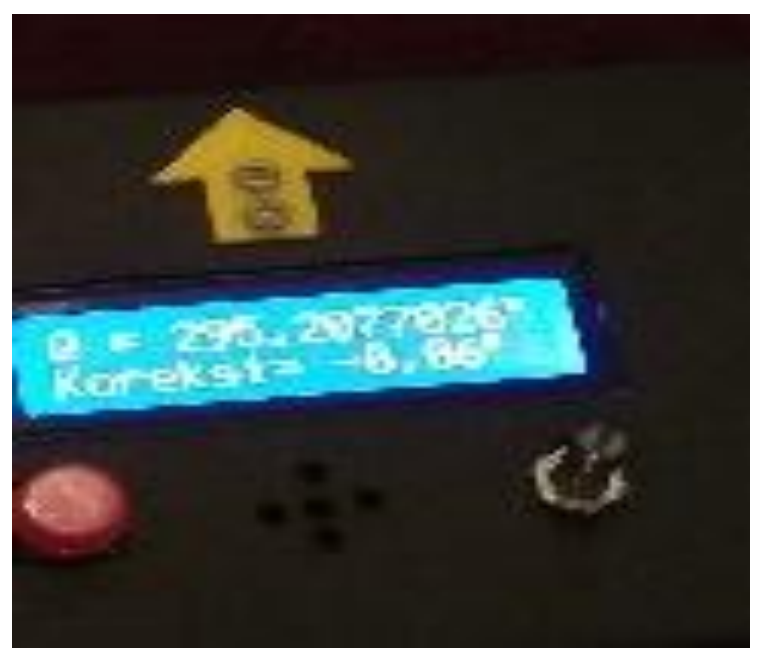

(a)

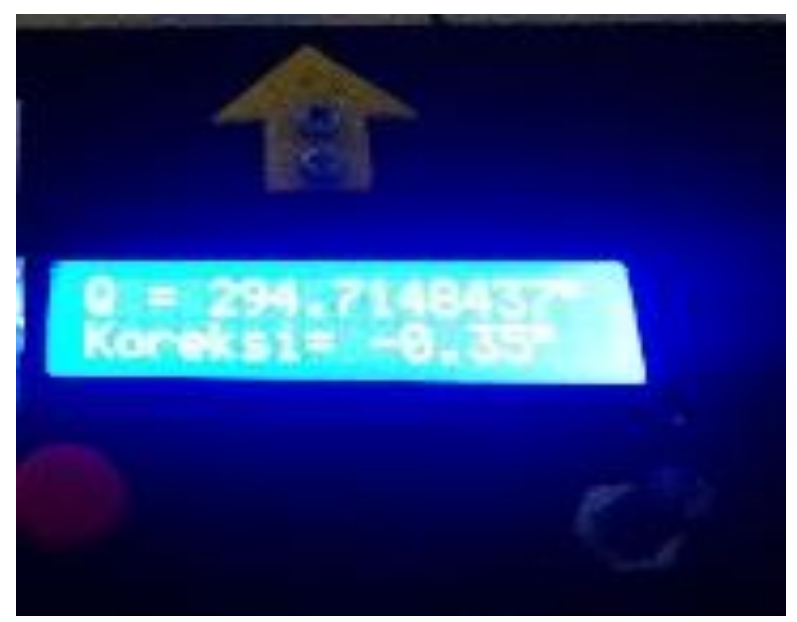

(b)

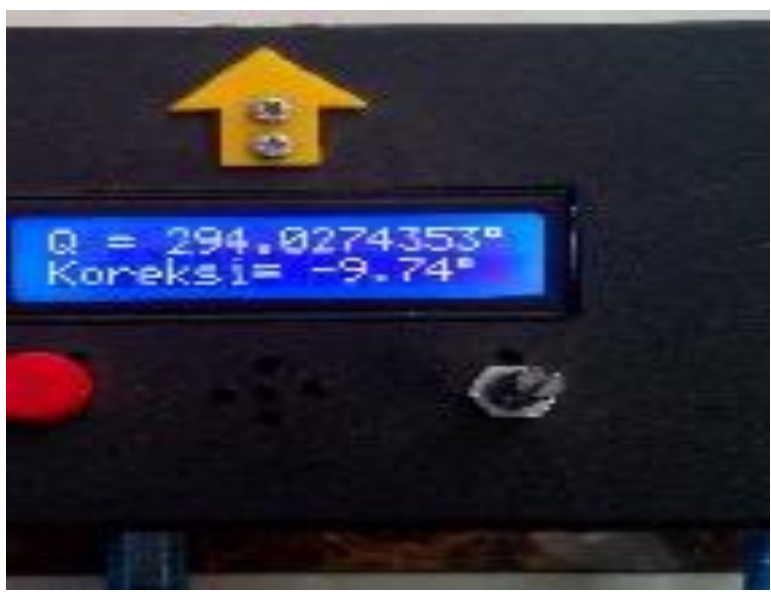

(c)

Fig. 2. Collecting the Data of some Masjid (a) Nur Asmaul Husna Mosque (b) Gedhe Kauman Mosque (c) Jami Nurul Muminin mosque

\section{ACKNOWLEDGMENT}

The author R. Apip Miptahudin was supported by Penelitian Dosen pemula (PDP) research Grant No. 0805/K4/KM/2018 from Ministry of Research, Technology and Higher Education of the Republic of Indonesia (KEMENRISTEKDIKTI) 2018. Mohamad Afendee Mohamed thank the Government of Malaysia for funding this research under the Fundamental Research Grant Scheme (FRGS/1/2018/ICT03/UNISZA/02/2) and also Universiti Sultan Zainal Abidin, Terengganu, Malaysia.

\section{REFERENCES}

1. F. Wajdi. Penerapan algoritma jean meeus dalam pengukuran arah kiblat dengan theodolite. Thesis. Institut Agama Islam Negri Wali Songo, 2012.

2. A. Meydiananda. Uji akurasi azimuth bulan sebagai acuan penentuan arah kiblat. Thesis, Institut Agama Islam Negri Wali Songo, 2012.

3. S. Hambali. Metode pengukuran arah kiblat dengan segitiga siku-siku dari bayangan matahari setiap saat. Thesis. Institut Agama Islam Negri Wali Songo, 2010.

4. A. Budiwati. "Tongkat istiwa, Global Positioning System (GPS) dan google earth untuk menentukan titik koordinat bumi dan aplikasinya dalam penentuan arah kiblat." Al-Ahkam, vol. 26, no. 1, pp. 65-92, 2016.

5. M. Raharto and D. J. Arifin. "Telaah penentuan arah kiblat dengan perhitungan trigonometri bola dan bayang-bayang gnomon oleh matahari." Jurnal Fisika Himpunan Fisika Indonesia, vol. 11, no. 1, pp. 23-29, 2011.

6. L. Hakim, R. B. Raharjo and D. D. Waluyo. "Prototype robot untuk menentukan arah kiblat dengan tanda shaf sholat." Program Kreativitas Mahasiswa-Karsa Cipta, pp. 1-8, 2014.

7. M. Rasyid, Posibilitas penentuan arah kiblat dengan lingkaran jam tangan analog. Thesis, Institut Agama Islam Negri Wali Songo, 2013.

8. N. H. El-Banjary. "Menentukan Arah Kiblat Dengan Hembusan Angin (Perspektif Fiqh dan Sains).” Jurnal Astronomi Islam dan Ilmu-Ilmu Berkaitan, vol. 2, no. 1, pp. 1-12, 2017.

9. A. A. Isa, Z. Zakaria, F. M. Johar and F. A. Othman. In-Flight Prayer Times and Qiblat Direction - A Preliminary Study. International RF and Microwave Conference Proceedings, Putrajaya, September 12-14 2006, 111-115, ISBN: 0-7803-9744-4.

10. M. Z. Ibrahim and M. Z. Norashikin. "Mobile Qibla and Prayer Time Finder using PDA and External Digital Compass. World Academy of Science, Engineering and Technology," International Journal of Electrical, Computer, Energetic, Electronic and Communication Engineering, vol. 4, no. 5, pp. 891-896, 2010.

11. M. Jassim, A. Al-Talabany and M. Mohammed. "Novel (RDQ ) method for Precise Qibla determination using GNSS Built in a Computer Software." Journal of Pure and Applied Science, vol. 28, pp. 356-362, 2016 . 